\title{
Learning Design to Improve Higher Order Thinking Skills (HOTS)
}

\author{
Dwi Rismi Ocy ${ }^{1, \text { a) }}$ \\ ${ }^{1}$ Universitas Negeri Jakarta, Rawamangun, Jakarta Timur

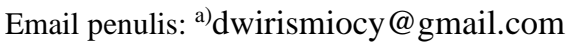

\begin{abstract}
The goal of this study is to explain a learning design that aims to improve students' higher-order thinking capabilities (HOTS) in mathematics learning, as well as the challenges they face during implementation. A literature review was chosen as the research method in this study. The descriptive approach of data analysis is used to describe the research findings before drawing conclusions. In short, the HOTS learning design must be integrated with learning object properties, basic aspects of generative learning, and the promotion of selected HOT elements. This type of learning design is both a knowledge acquisition and a cognitive tool for improving HOTS.
\end{abstract}

Keywords: High order thinking, learning design, HOTS

\begin{abstract}
Abstrak
Tujuan penelitian ini adalah untuk mendeskripsikan desain pembelajaran yang bertujuan untuk meningkatkan kemampuan berpikir tingkat tinggi (HOTS) siswa dalam pembelajaran matematika dan mendeskripsikan kendala yang dihadapi dalam proses pelaksanaannya. Metode penelitian yang digunakan dalam penelitian ini adalah studi pustaka. Analisis data menggunakan metode deskriptif, yaitu menggambarkan hasil penelitian dan kemudian menarik kesimpulan. Desain pembelajaran HOTS harus dipadukan dengan atribut objek pembelajaran, elemen dasar pembelajaran generatif, dan promosi elemen HOTS terpilih. Desain pembelajaran ini tidak hanya sebagai alat pemerolehan pengetahuan, tetapi juga alat kognitif untuk meningkatkan HOTS.
\end{abstract}

Kata kunci: Kemampuan berpikir tingkat tinggi, desain pembelajaran, HOTS

Copyright (c) 2021 Ocy

$\triangle$ Corresponding author:

Email Address: dwirismiocy@gmail.com

Received 2 Februari 2021, Accepted 3 Agustus 2021, Published 20 Agustus 2021

https://doi.org/10.21009/jrpmj.v3i2.22265

\section{INTRODUCTION}

HOTS is critical in applying, linking, and modifying existing knowledge in order to solve new issues effectively (Thomas \& Thorne, 2009). Higher-order thinking necessitates the application of new information or knowledge that has already been learned, as well as the manipulation of that information, in order to obtain the ability to respond in new situations. One of the qualities that students should develop through teaching and learning is higher-order thinking capacity (HOTS). Bloom's thinking skills are divided into two categories by Schraw \& Robinson (2011) low-level thinking skills, which are made up of knowledge, understanding, and application, and high-level thinking skills, which are made up of knowledge, understanding, and application. Analysis, synthesis, and evaluation are examples of advanced thinking skills. Each category's description and keywords are shown in Table 1.

Table 1 Description and Key Word of Bloom's Taxonomy

\begin{tabular}{cl}
\hline Category & \multicolumn{1}{c}{ Keywords } \\
\hline & $\begin{array}{l}\text { Remembering: Mention the definition, state the structure, pronounce, } \\
\text { imitate the pronunciation, repeat, state the definition }\end{array}$ \\
\hline
\end{tabular}




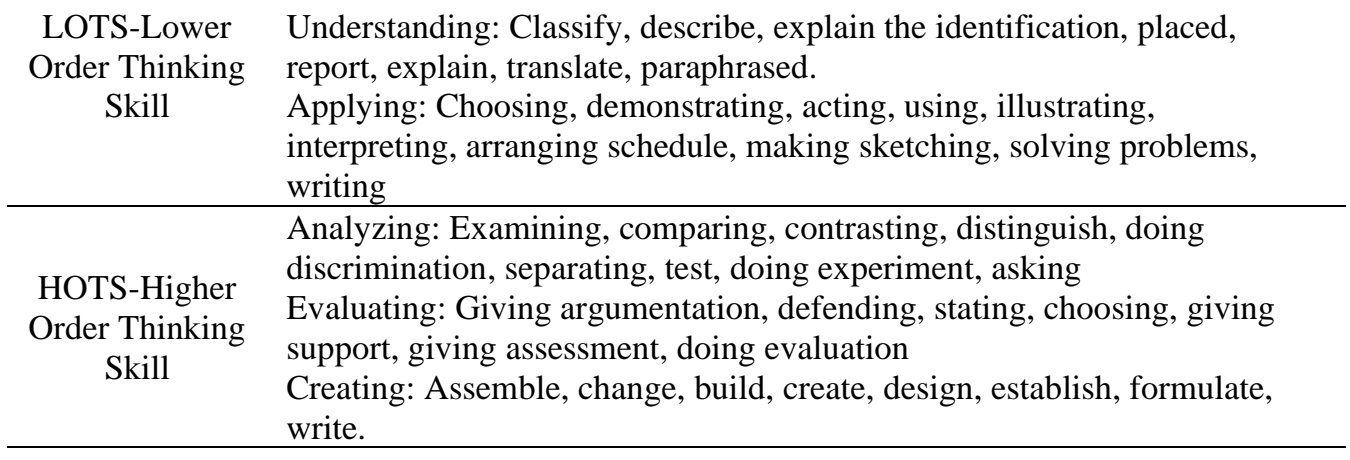

HOTS is characterized as the transition between the three highest levels of knowledge in the cognitive dimensions (analysis, evaluation, and production) and concepts, procedures, and metacognition in the revised Bloom taxonomy (Maulidiya et al., 2018; Rahmi, 2021; Thompson, 2008). There is only one cognitive dimension in Bloom's taxonomy, whereas Anderson and Krathwohl's taxonomy has two. The knowledge dimension is the first dimension, while the cognitive process dimension is the second. The variables to test advanced thinking capacity, according to Krathwohl (2002), are analysis, evaluation, and creation. As a result, HOTS is a thinking ability that involves not only the ability to remember, but also the ability to analyze, evaluate, and create (Anderson et al., 2001). Table 2 shows Anderson and Krathwohl's two-dimensional views, which are used in higher-order thinking, as well as the classification of their operative verbs.

Table 2. Bloom's taxonomy of dimentional revision and Examples of operational verbs for higher order thinking

\begin{tabular}{|c|c|c|c|}
\hline \multirow{2}{*}{$\begin{array}{l}\text { The Knowledge } \\
\text { Dimension }\end{array}$} & \multicolumn{3}{|c|}{ The Cognitive Process Dimension } \\
\hline & C4 (Analyze) & C5 (Evaluate) & C6 (Create) \\
\hline Factual & $\begin{array}{l}\text { Making structure, } \\
\text { classifying }\end{array}$ & $\begin{array}{l}\text { Comparing, } \\
\text { correlating }\end{array}$ & Joining \\
\hline Conceptual & Explain, Analyze & Examine, interpret & Planning \\
\hline Procedural & Distinguish & Conclude, resume & $\begin{array}{c}\text { Arrange, } \\
\text { formulate }\end{array}$ \\
\hline Metacognitive & Create, find & Make, assess & Realization \\
\hline
\end{tabular}

\section{Reasons to improve HOTS through Teaching and Learning}

The Ministry of Education has undertaken a number of transformation initiatives and curricular innovations in order to stay up with current societal changes, both locally and globally. Although improving students' thinking skills is one of the goals of national education, however, efforts to generate pupils who are capable of higher order thinking have had minimal success thus far, and no strong evidence of a national culture of creativity, invention, and innovation can be found.

The purpose of any of the HOTS cognitive taxonomies is to educate students how to transfer information and think critically. "Thinking ability" refers to pupils' ability to apply what they've learned in the classroom to new situations. "New" in this context refers to applications that the student has not 
considered before, rather than anything that is globally new. Students' ability to relate their learning to components other than those they were taught to associate with it is referred to as higher-order thinking.

\section{METHOD}

A literature review was chosen as the research method in this study. Literature research was used to get information. Journal articles about the topic of discussion were used as the source of information. The article's review focuses on a review of the most recent journal publications on highorder thinking skills. The descriptive approach of data analysis is used to describe the research findings before drawing conclusions.

\section{RESULTS AND DISCUSSION: HOTS LEARNING DESIGN}

The teaching of HOTS should be properly prepared according to the course material, teaching time, and students' abilities by the teachers. Design failure, on the other hand, will have negative consequences. All aspects of thinking ability must be meticulously prepared and implemented in order to avoid failure. As a result, the timetable serves as a springboard for teachers to operate wisely and creatively in the classroom when teaching and learning HOTS. There are a lot of strategies to get children excited about learning, but only a few learning designs work. To create your own learning design, carefully follow all of the procedures listed below.

\section{Follow HOTS Characteristics}

HOTS has several characteristics, according to Resnick (1987: 3), including: (a) nonalgorithmic, which means that the action steps cannot be completely determined from the start; (b) complex, which means that it cannot be directly seen from a specific angle/Prediction steps; (c) produce multiple solutions; (d) involve differences in opinions and interpretation; (e) involve multiple standards; (f) entails uncertainty; (g) necessitates mental independence; (h) has a powerful meaning; I necessitates efforts.

\section{Real and or New Life Problems}

Students can think more creatively, better grasp the world, and observe in class if they are given fresh practical issues. This may pique their interest, leading to the discovery of new problems they were previously unaware of. More discussion activities can be carried out in the classroom with practical concerns. It is the teacher's role to guide students in their investigation and research. The problem in developing a HOTS learning design is determining how to ask questions that support the growth of students' thinking skills in a way that is compatible with their cognitive ability (Arthur et al., 2018). These questions are unusual and open-ended inquiries. Several learning models are currently in use that 
prioritize the utilization of unusual challenges and are centered on the axis in the implementation process. Miri, David, \& Uri (2007) demonstrated the effectiveness of this method.

\section{Minimize Teacher Domination}

In order to attain the learning goals to the maximum extent possible, there are always learning goals to be achieved in each learning process. In order to motivate students to participate in the learning process, educators must be able to design/write engaging learning concepts. In the past, we used the teacher-centered model to familiarize ourselves with terminology and learning methods; however, this model has begun to shift, and the current emphasis on learning more emphasizes students' enthusiasm for the learning process, which is commonly referred to as student-centered. HOTS are exercises that demand students to actively participate in the learning process. When creating a learning system for HOTS, the main goal is to reduce teacher control and increase students' active participation in the learning process.

\section{Connect Mathematics with other Disciplines (Mathematical Connections)}

"The ability to recognize and use the connection between mathematical ideas; understand how mathematical ideas are connected and depend on each other to produce a coherent whole; the environment outside of mathematics Understanding and applied mathematics," according to the NCTM's "Principals and Standards of School Mathematics" (NCTM, 2000). Mathematics teaching is viewed as an inherent aspect of mathematics instruction at all stages of education as a result of experiencing the relationship between various forms of mathematical knowledge.

\section{Scaffolding Instructions}

Scaffolding, according to Agustina \& Setianingsih (2017), is a guiding procedure that can help students bridge the gap between what they now know and what they should know. Higher scaffolding, on the other hand, may have a detrimental impact on pupils' capacity to execute activities independently and rely on advice from others. Furthermore, Eliyasni, Kenedi, \& Sayer, (2019) determined that no actual learning occurs if the teacher just delivers thorough instructions and assigns assignments to the pupils. Scaffolding does not change the work, but it does simplify and facilitate it. Scaffolding is a temporary aid that will be phased off as pupils progress, learn, and gain new skills.

Contingency, fading, and responsibility shifting are three fundamental features of scaffolding. Resilience is a key indicator of a program's success because it refers to tailoring support to the requirements of students. The temporary assistance can be adjusted based on the student's response. When students have difficulty completing activities, temporary scaffolding ensures that they are never alone. The second factor is decline, which refers to the gradual cessation of assistance, whereas responsibility transfer refers to the process of passing responsibility for task completion to students. 


\section{Mathematical Representations}

Representation was proposed as a process requirement in the "School Mathematics Principles and Standards" (NCTM, 2000). "The nomenclature refers to both the process and the product as the act of recording a given form of mathematical concept or relationship and the form itself," according to the NCTM (2000) publication. All students should now: (1) develop and use representations to organize, record, and exchange mathematical ideas; (2) choose, implement, and interpret among mathematical representations to find solutions; and (3) use notation to represent and explain physical, social, and mathematical phenomena, according to the new process standard.

Improving HOTS through employing a variety of representations to express mathematical ideas. There are a variety of tools and options available to produce a variety of methods to describe math issues, including graphic, diagram, statistic, and many others. By looking at the problem in a variety of ways, students can learn new approaches to tackle it. The importance of adopting diverse representations is that it allows students to acquire and master new concepts while also helping them grasp earlier mathematics subject(Ikram \& Ikram, 2021; Kosiret et al., 2021; Satriawati et al., 2018).

These descriptions demonstrate the importance of pupils using expressions/representation to develop and comprehend key abstract concepts in mathematics. It is critical for students to be able to employ many forms of representations flexibly to research in order to strengthen their high-order thinking skills, in which students have a hard time learning to use representational forms in mathematics.

\section{Mathematical Modelling Approach}

Equations or other mathematical expressions are commonly used in mathematical models. According to Arseven (2015), in some systems, the relationship's intricacy cannot be physically represented, or the physical representation is difficult to construct and takes time. As a result, symbols can be utilized with more abstract models. The majority of management science analysis is carried out utilizing mathematical models and symbols. These are more generic than specific and can be used to describe a variety of situations. Furthermore, it is simple to alter for the purposes of experimentation and prediction. When the concept of a model is extended to the realm of mathematics, it is useful to know how essential or meaningful the impact of variables on the model is from a quantitative standpoint. Finally, mathematical modeling might be characterized as the application of mathematics to explain and define real-life events, to test concepts, and to make predictions about real-life events. The explicit and interrelationships between variables and other aspects that are considered vital to solve the problem are described in mathematical models.

\section{Technology-based Teaching}

Students are typically taught how to use mathematics software (such as GeoGebra, Cabri, and Geometers Sketchpad) as a tool and medium for teaching activities in technology-based teaching. The 
sections created show how the program can be used to teach various subjects. Technology, as a knowledge tool, is causing changes in impact and efficiency. This information tool has the potential to alter the topics that are taught in the classroom. Use modern technology to collect, organize, and assess problem-solving and innovative tools that will help teachers and students learn more effectively. However, the quality of technology use includes not just how the technology is used, but also how it is integrated into the material, which is especially crucial in learning.

Teachers that are familiar with Technological Pedagogical Content Knowledge (TPACK) are thought to be capable of figuring out how to incorporate technology into certain material and teaching techniques. TPACK is the model's center, according to Harrington, Driskell, Johnston, Browning, \& Niess (2019) represents the following pieces of knowledge: (1) Pedagogical Content Knowledge (PCK): How to teach certain content-based materials; (2) Technological Content Knowledge (TCK): Choosing and using technology and knowledge content for communication; (3) Technological Pedagogical Knowledge (TPK): How to employ certain teaching strategies that are most appropriate.

Teachers can demonstrate their Technological Pedagogical Content Knowledge (TPACK) skill by understanding: (a) how technological tools affect students' knowledge of topics; and (b) how technical tools change instructional methodologies and material representations to teach certain topics (Muhtadi et al., 2018). Teachers must learn how to have the ability of a certain topic domain TPACK to make learning more successful, according to Harrington et al. (2019), and design-based principles must be developed in the TPACK teaching process. The outcomes of employing technological tools to study models can assist students in deepening their comprehension of mathematics as well as the impact of mathematics teaching methods on teachers.

Assestment: Designing tasks that allows students to analyze, sythesise, and justify

Successful task design necessitates making the course's basic materials a requirement for completing the performance. We want to know that students can effectively apply their knowledge and resources. The goal is to create a realistic simulation, and the task, like any simulations, case studies, or experiential exercises, requires a lot of context information. The context is rich if it enables numerous ways, styles, and solutions and requires strong judgment to achieve effective outcomes. You must delight the intended audience, make the design truly functional, or generate an aesthetic impression that makes the final product proud or frustrating.

Over-reliance on traditional evaluation models (such as testing), according to (Haladyna, 1997), may be detrimental to the assessment of higher order thinking. Even with rigorous restrictions, typical examinations tend to overestimate students' "knowledge" while underestimating their "knowledge technical expertise," or intellectual performance. Wiggins (1992) suggested that the assessment of higher-order thinking should be based on explicit criteria and offer students with accurate information about the topic being assessed. "Difficult tasks aren't cryptic tasks." Goals and standards are known by all real-world performers, not only those who complete work ahead of schedule. Their training and 
rehearsals are guided by this information. Students will never have to ask themselves, "Is this correct?" "Have I completed it?" "How am I getting along?" "Is this what I'm looking for?" The job structure is out of order in a "real" question, but it is clearly defined: goals, requirements, or intended results are understood, but how to execute them is not.

\section{CONCLUSION}

In conclusion, HOTS learning design must be paired with learning object properties, basic generative learning features, and the promotion of selected HOT elements. This type of learning design is both a knowledge acquisition and a cognitive tool for improving HOTS. In addition, it teaches students how to become "learning designers." The following are some of the most notable elements of the learning design: (1) It is completely invented of a knowledge field that is separated into smaller parts (learning objects) and is adaptable, reusable, and might even be linked; (2) Create many representation modalities utilizing fundamental computer tools; (3) build a collaborative learning environment for knowledge sharing; (4) Providing a learning environment in which students were in charge of evaluating and guiding themselves, in which students could reflect, improve, construct concepts and create or design; (5) Create multiple types of assessments utilizing real-life problems; (6) Giving an environment for students to parctice and test their own concepts; (7) Provide a dynamic environment favorable to active participation.

\section{REFFERENCES}

Agustina, R., \& Setianingsih, R. (2017). The use of scaffolding to train students' skills in solving PISA's problem (Programme Internationale for Student Assessment) involving HOTS (Higher Order Thinking Skills). Jurnal Ilmiah Pendidikan Matematika: MATHEdunesa.

Anderson, L. W., Krathwohl, D. R., \& Bloom, B. S. (2001). Revised Bloom's Taxonomy. In A Taxonomy for Learning, Teaching, and Assessing: A Revision of Bloom's Taxonomy of Educational Objectives.

Arseven, A. (2015). Mathematical Modelling Approach in Mathematics Education. Universal Journal of Educational Research. https://doi.org/10.13189/ujer.2015.031204

Arthur, Y. D., Owusu, E. K., \& Asiedu-addo, S. (2018). Connecting Mathematics To Real Life Problems : A Teaching Quality That Improves Student $s$ ' Mathematics Interest. Ato Kwamina Arhin. Journal of Research \& Method in Education.

Eliyasni, R., Kenedi, A. K., \& Sayer, I. M. (2019). Blended Learning and Project Based Learning: The Method to Improve Students' Higher Order Thinking Skill (HOTS). Jurnal Iqra' : Kajian Ilmu Pendidikan. https://doi.org/10.25217/ji.v4i2.549

Haladyna, T. M. (1997). Writing Test Items to Evaluate Higher Order Thinking. In Writing Test Items to Evaluate Higher Order Thinking.

Harrington, R. A., Driskell, S. O., Johnston, C. J., Browning, C. A., \& Niess, M. L. (2019). Technological Pedagogical Content Knowledge. In TPACK. https://doi.org/10.4018/978-15225-7918-2.ch016 
Heong, Y. M., Othman, W. B., Yunos, J. B. M., Kiong, T. T., Hassan, R. Bin, \& Mohamad, M. M. B. (2011). The Level of Marzano Higher Order Thinking Skillsamong Technical Education Students. International Journal of Social Science and Humanity. https://doi.org/10.7763/ijssh.2011.v1.20

Ikram, M., \& Ikram, M. (2021). Analysis of The Occurrence of Reversible Reasoning for Inverse Cases: A Case Study on The Subject Adjie. International Journal of Progressive Mathematics Education, 8435(1), 1-15. https://doi.org/10.22236/ijopme.v1i1.6635 To

Kosiret, A., Indiyah, F. H., \& Wijayanti, D. A. (2021). The Use of Generative Learning Model in Improving Students' Understanding of Mathematical Concepts of Al-Azhar 19 Islamic High School. International Journal of Progressive Mathematics Education, 1(1), 1626. https://doi.org/10.22236/ijopme.v1i1.6593

Krathwohl, D. R. (2002). A Revision of Bloom's Taxonomy: An Overview, Theory Into Practice. Theory Into Practice.

Maulidiya, D., Susanta, A., \& Irsal, N. A. (2018). Model Investigasi Berbantuan Geogebra pada Geometri Bidang Abstrak. Jurnal Riset Pendidikan Matematika Jakarta, 1(2013), 1521. http://journal.unj.ac.id/unj/index.php/jrpmj/article/view/4969/3664

Miri, B., David, B. C., \& Uri, Z. (2007). Purposely teaching for the promotion of higher-order thinking skills: A case of critical thinking. Research in Science Education. https://doi.org/10.1007/s11165-006-9029-2

Muhtadi, D., Wahyudin, Kartasasmita, B. G., \& Prahmana, R. C. I. (2018). The Integration of technology in teaching mathematics. Journal of Physics: Conference Series. https://doi.org/10.1088/1742-6596/943/1/012020

NCTM. (2000). Executive summary: principle and standards for school mathematics. Journal of Equine Veterinary Science.

Rahmi, A. (2021). Tahap Preliminary Research Pengembangan Media Pembelajaran Berbasis Komputer pada Materi Transformasi SMA / MA. Jurnal Riset Pendidikan Matematika Jakarta, $3(1), 14-18$.

Satriawati, G., Musyrifah, E., \& Purwanto, S. (2018). Pengaruh Strategi Pembelajaran Active Knowledge Sharing $t$ terhadap Kemampuan Komunikasi Matematik Siswa. Jurnal Riset Pendidikan Matematika, 1(1), 45-51. journal.unj.ac.id/unj/index.php/jrpmj/article/download/4961/3659

Schraw, G., \& Robinson, D. H. (2011). Assessment of Higher Order Thinking Skills. Current Perspectives on Cognition, Learning and Instruction. In IAP - Information Age Publishing, Inc.

Thomas, G., \& Thorne, A. (2009). How To Increase Higher Level Thinking. Metarie, LA: Center for Development and Learning.

Thompson, T. (2008). Mathematics teachers' interpretation of higher-order thinking in Bloom's taxonomy. International Electronic Journal of Mathematics Education.

Wiggins, G. (1992). Creating Tests Worth Taking. Educational Leadership

How to cite : Ocy, D. R., 2021. Learning Design to Improve Higher Order Thinking Skills (HOTS). Jurnal Riset Pendidikan Matematika Jakarta. 3(2). 34-41. https://doi.org/10.21009/jrpmj.v3i2.22265

To link to this article: https://doi.org/10.21009/jrpmj.v3i2.22265 